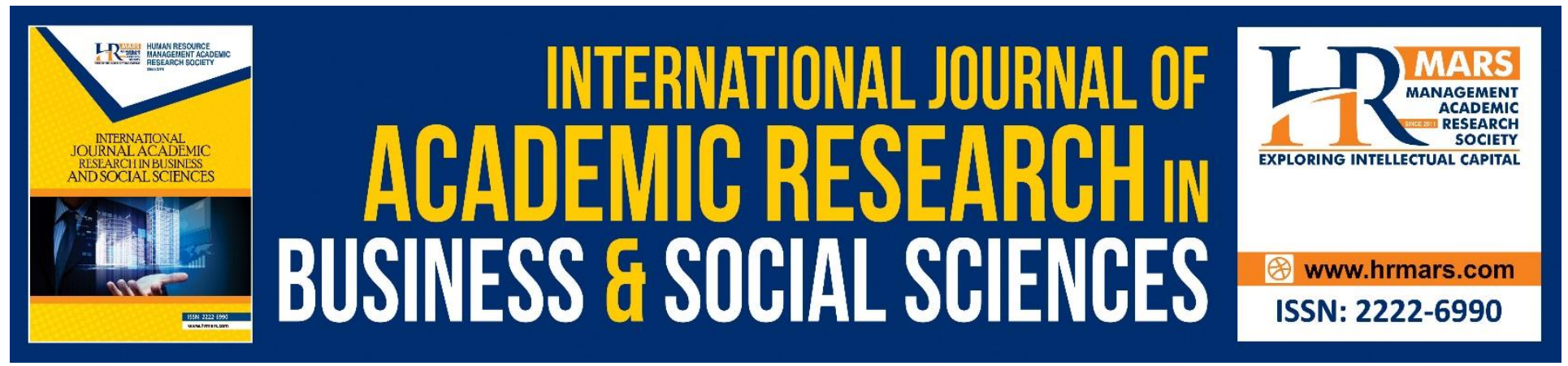

\title{
Evaluation of Validation Process of an Instrument for Measuring Pre-Service Mathematics Teachers' Level of Knowledge of Secondary School Mathematics Subject Matter
}

Ibrahim Muhammad Alhaji, Wun Thiam Yew

To Link this Article: http://dx.doi.org/10.6007/IJARBSS/v10-i7/7452

DOI:10.6007/IJARBSS/v10-i7/7452

Received: 06 April 2020, Revised: 09 May 2020, Accepted: 19 June 2020

Published Online: 20 July 2020

In-Text Citation: (Alhaji \& Yew, 2020)

To Cite this Article: Alhaji, I. M., \& Yew, W. T. (2020). Evaluation of Validation Process of an Instrument for Measuring Pre-Service Mathematics Teachers' Level of Knowledge of Secondary School Mathematics Subject Matter. International Journal of Academic Research in Business and Social Sciences, 10(7), 497-506.

Copyright: (C) 2020 The Author(s)

Published by Human Resource Management Academic Research Society (www.hrmars.com)

This article is published under the Creative Commons Attribution (CC BY 4.0) license. Anyone may reproduce, distribute, translate and create derivative works of this article (for both commercial and non-commercial purposes), subject to full attribution to the original publication and authors. The full terms of this license may be seen at: http://creativecommons.org/licences/by/4.0/legalcode

Vol. 10, No. 7, 2020, Pg. 497 - 506

Full Terms \& Conditions of access and use can be found at http://hrmars.com/index.php/pages/detail/publication-ethics 


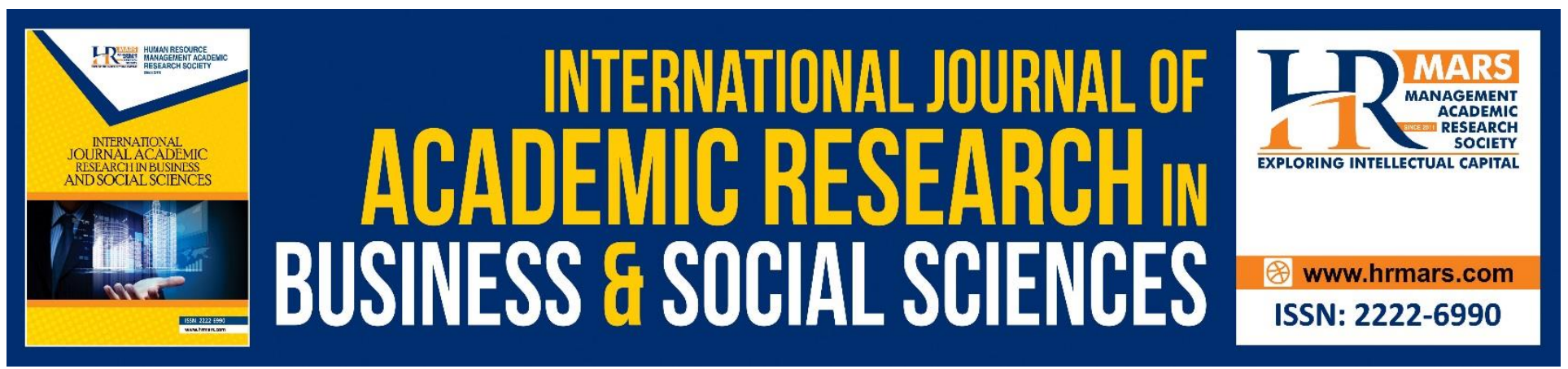

\title{
Evaluation of Validation Process of an Instrument for Measuring Pre-Service Mathematics Teachers' Level of Knowledge of Secondary School Mathematics Subject Matter
}

\author{
Ibrahim Muhammad Alhaji ${ }^{1}$, Wun Thiam Yew ${ }^{2}$ \\ ${ }^{1}$ Department of Science Education, Sule Lamido University Kafin Hausa, Jigawa State, Nigeria, \\ ${ }^{2}$ School of Educational Studies, Universiti Sains Malaysia, Penang, Malaysia
}

\section{Abstract}

The purpose of this study is to evaluate the validation process of School Mathematics Content Test. The instrument was developed to assess final year pre-service mathematics teachers' level of knowledge of secondary school mathematics subject matter, in Kano University, Nigeria. The validity of the instrument was established based on table of specification and panel of experts comment and suggestion on the quality and suitability of items of the instrument. The scale was revised and modified based on the comments and suggestion of panel of experts. Item content validity index (I$\mathrm{CVI}$ ) and scale content validity index (S-CVI) was calculated based on panel of experts' judgment on the quality of the items and coverage on contents areas to be explored. The content validity of the instrument yielded S-CVI/UA score of 1 and S-CVI/Ave score of 1.The results of the analysis has revealed that the instrument has excellent face and content validity, which depict the efficiency of the scale development process. Therefore, the instrument can be used as efficient and reliable instrument for measuring level of knowledge of secondary school mathematics subject matter in Nigeria.

Keywords: Evaluation, Validation, Instrument, School Mathematics, Level of Knowledge.

\section{Introduction}

Competency/mastery of subject matter refers to the possession of adequate skills, attitude and knowledge which will enable students to successfully learn new knowledge or ideas. It enables teachers to provide effective classroom instruction. In teaching and learning process competency provides students with opportunity to transfer their ideas or knowledge into new situation and achieve significantly. However, it provides teachers with more opportunities of transforming complex problem into simpler in order to facilitate students learning. Rabbitt (2014) has defined competency as: "the capability to apply or use the set of related knowledge, skills, and abilities required to successfully perform 'critical work functions' or tasks in a defined work setting" (p. 1). 
INTERNATIONAL JOURNAL OF ACADEMIC RESEARCH IN BUSINESS AND SOCIAL SCIENCES Vol. 10, No. 7, July, 2020, E-ISSN: 2222-6990 @ 2020 HRMARS

Previous literature has shown that competency is the possession of adequate skills, knowledge and abilities required for success in a given task or workplace, it specified the level of knowledge and skills attained in achieving given task (Misko, 2010). In teaching and learning process, competency/mastery in a given subject serves as basis standards that specified the level of knowledge and skills attained by school teachers. This is to say that a competent teacher is someone who attained highest level of knowledge of subject matter. A competent teacher is expected to exhibit higher level of knowledge of the subject matter more than his students, and able to perform specified duties base on knowledge, skills, experience and training he received.

Mathematics teacher's competency or mastery of the subject matter is assess through level of knowledge of the subject matter they possess (Anakwue, 1997). Similarly, Rabbit (2014) posit that teachers' competency may be assessed based on prior theoretical knowledge they received. Mathematics teachers' competency or mastery of subject matter can be assessed based on the following mathematics teaching skills:

Critical Thinking: This refers to the teachers' ability to evaluate or synthesis mathematical problem, ability to use both deductive and inductive reasoning to generalize or justify argument.

Problem Solving: This is concern with using prior knowledge to solve or identify mathematical problems. It however, concern with mathematics strategies or process in order to generate solution or support decision making.

Creativity and Innovation: This is concern with formation of mathematics ideas or concept using flexible thinking or approach.

Collaboration: This is concern with collaborating learning which will enhance and support mathematics learning and application of mathematics. Mathematics ideas and strategies are shared with aims of students support and development.

All these mathematics teaching and learning competencies are necessary for effective classroom instruction. Therefore, it's necessary for school mathematics teachers to possess them. A considerable number of researchers have suggested a percentage of correct responses or right answers in a given test for deciding students' competency/ mastery level. $74 \%$ to $80 \%$ correct responses in a given multiple choice test was suggested as percentage for deciding students competency/ mastery in a given subject (Anakwue, 1997; Thormas and Eric, 2013; Thorndike \& Hegen, 1977). Pre-service mathematics teachers are prospective school teachers and are expected to exhibit higher level of knowledge of the subject matter more than their students, since they have been trained to master their subject areas, acquire adequate skills and teaching strategies which will enable them to develop efficient strategies for effective classroom instruction. Thus, pre-service mathematics teachers must possess adequate level of mastery of the subject matter for which they have been train to teach. Their level of mastery must be above the students' mastery level, this could enable them to discharge their duty effectively and meet the expectation from quality school mathematics teachers.

The expectation for effective teaching and learning process is for school teachers to exhibit higher level of knowledge of the subject matter more than their students and be able to guide them throughout the lesson (Ibrahim et al., 2020). The national policy objectives of providing quality teacher education training, is for school teachers to help government to provide quality education, prepare students for social life and prepare students for higher education (NPE, 2004). 
INTERNATIONAL JOURNAL OF ACADEMIC RESEARCH IN BUSINESS AND SOCIAL SCIENCES Vol. 10, No. 7, July, 2020, E-ISSN: 2222-6990 @ 2020 HRMARS

The policy of education reiterates the objectives of providing quality education at level of education as; "no education system may rise above the quality of its teachers, teacher education shall continue to be given emphasis in all educational planning and national development" (NPE, 2004, p. 39).

The policy states the objectives of providing teacher education training in the country as follows (NPE, 2004, p. 39):

1. To provide highly motivated, conscientious, and efficient classroom teachers for all levels of educational system.

2. To encourage further spirit of enquiry and creativity in teachers.

3. To help teachers to fit into the social life of the community and society at large and to enhance their commitment to nation objectives.

4. To provide teachers with intellectual and professional background adequate for their assignment and to make them adaptable to any changing situation not only in the life of their country but in the world.

In reference to national policy objective of providing quality teacher education training, and teachers' competencies/ mastery of subject matter, there is course of alarm over the quality of school mathematics teachers and their efficiencies in discharging their duty. A growing body of literatures has revealed that the recently graduated school mathematics teachers have inadequate mastery of their subject area (Anaduaka \& Okafor, 2013; Ibrahim et al., 2018; Ibrahim et al., 2020; Kuiper, Thomas, \& Olorisade, n.d) and pedagogical skills to the extent that many stakeholders raised their concern on the process through which they obtained the certificate they possess (Ibrahim et al, 2018; Odia \& Omofonmwan, 2007; Omorogbe \& Ewansiha, 2013). Similarly, Usman (2015) posits that some of the pre-service mathematics teachers have low ability in constructing mathematical equation, expression and their problem, their understanding of school mathematics subject matter is more of comparable with understanding of the students they were teaching (Musa, 2011).

Hence, the goal of teacher education training in the national policy objective is to train and prepare school teachers with intellectual and professional background adequate for their teaching assignment. This national policy objectives of teacher training is just a mere wish, since majority of the graduated school mathematics teachers have inadequate mastery of their subject area and cannot be relied upon to raised the quality of schools. Consequently, the researcher deem it pertinent to conduct the study to evaluate the validation process of the instrument used for measuring final pre-service mathematic teachers' level of knowledge of secondary school mathematics subject matter.

There is also little research about the validity and reliability of the instruments used in measuring final year pre-service mathematics teachers' level of knowledge of secondary school mathematics subject matter. Realizing the gap in the extent literature, more research is needed for evaluation of the validity and reliability of the instrument. To our knowledge, no research has been carried out on the validity and reliability of the instrument. To address these gaps the study has set objective to evaluate the validation process of the instruments, and provides evidence whether the instrument was valid and reliability for measuring final year pre-service mathematics teachers' level of knowledge of secondary school mathematics subject matter. This is because the process is very essential in assessment, as it informs educational measurement and evaluators on whether the instrument is good or not for the assessment. 
INTERNATIONAL JOURNAL OF ACADEMIC RESEARCH IN BUSINESS AND SOCIAL SCIENCES Vol. 10, No. 7, July, 2020, E-ISSN: 2222-6990 @ 2020 HRMARS

\section{Validity of Instrument}

Validity and reliability are essential aspect of assessment which helps educational researchers to establish the effectiveness of research instruments. Validity and reliability of the instrument are very essential in deciding whether an instrument is good or not for the assessment (Kaplan \& Saccuzzo, 2005; Masuwai \& Saad, 2017; McIntire \& Miller, 2007). The validity and reliability of the instruments is said to be established, when an instrument measure what its purported to measure (Validity), and when it is consistently measure what it is purported to measure (Reliability). If an instrument provides evidence of validity and reliability is consider valid and reliable instrument for education assessment. Masuwai and Saad (2017) argued that most educational researchers and evaluators presented their work without sufficient evidence of validation. As educational research and evaluation studies received growing recognition in the field of teaching and learning, particularly in assessing students' learning outcomes and teachers' effectiveness, the process through which the validity and reality of the instrument was established are crucial in deciding the effectiveness of the instrument in assessment.

The process through which the validity and reliability of School Mathematics Content Test was established, are very essential to both teacher training institutions and stakeholders in deciding the quality and effectiveness of final year pr-eservice mathematics teachers in teaching secondary school mathematics subject matter. Musuwai and Saad (2017) cited Wilson et al. (1997) who posit that for studies with aims of improving teachers' quality there is need for valid, reliable and comparable performance data. Therefore, it is imperative for this study to examine the validation process of the instrument used in measuring final year pre-service mathematics teachers' level of knowledge of secondary school mathematics subject matter in Nigeria.

\section{Methodology}

The research design under this study was descriptive and development of instrument. Different validation process were used (i.e. Table of specification, face and content validity) in order to ensure the accuracy, reliability, appropriateness of the instrument and free from inaccurate estimate of the outcomes. For any research instrument to be free from biased and inaccurate estimate of outcomes the instrument should be valid and reliable (Chiwaridzo et al., 2017; Sikorskii \& Noble, 2013). Similarly, an instrument is considered to be reliable when similar results were obtained at different occasion using the same procedures (Golding et al., 2015; Wong et al., 2012). The subjects under this study were mainly final year pre-service mathematics teachers who undergone teaching practices at various secondary schools in Nigeria. The samples of the study were randomly selected.

\section{School Mathematics Contents Test Development and Discussion of the Finding}

This section discuses the process of School Mathematics Contents Test development and discussion of the finding. The instrument was developed in different stages which include: conceptual and operational definition, generating of item pool, scale development, and expert review. Thereafter, finding of the study was discussed.

\section{Developing Conceptual and Operational Definition}

The researcher carefully studied Secondary School Mathematics curriculum and Nigerian Educational Research and Development Council (NERDC, 2019), different information were gathered on the required mathematics subject matter knowledge and skills, expected for each secondary 
INTERNATIONAL JOURNAL OF ACADEMIC RESEARCH IN BUSINESS AND SOCIAL SCIENCES

Vol. 10, No. 7, July, 2020, E-ISSN: 2222-6990 @ 2020 HRMARS

school mathematics teacher to exhibit. Based on the information gathered from the above documents studied, pre-service mathematics teachers are expected to exhibit higher level of knowledge of school mathematics subject matter, and they should be able to teach any topic that was presented to them.

\section{Generating Item Pool}

In this study, the aim was to evaluate validation process of School Mathematics Content Test Instrument in Nigeria. Different task were adapted from (NERDC, 2019), secondary school mathematics curriculum and literature for assessing pre-service mathematics teachers level of knowledge of school mathematics subject matter. Research literature has shown that item pool generating requires a lot of tasks in generating large pool of items that are relevant to the construct under investigation, for inclusion in the scale (DeVellis, 2012).

\section{Designing Scale}

General mathematics curriculum for senior secondary school, from class four to six mathematics lesson exercise (General mathematics, 2018) contains items for each mathematics subject matter, measuring students' level of knowledge, the items were based on the objectives of learning mathematics (i.e. general knowledge skill, application skill, process and problem solving skill). Since the study focus on pre-service mathematics teachers' level of knowledge of school mathematics subject matter, items that are related to secondary school mathematics subject matter were included.

Moreover, all items that were included in the instrument, were submitted to three expert from mathematics education and two experts from psychometric and educational evaluation who were concerned with teaching and preparation of mathematics teachers to assess the items in the instrument in terms of relevance to the study, coverage of content areas to be explored, appropriateness and clear instruction. Based on the comment received from the experts, items were added, rephrased, or removed accordingly. To ensure appropriateness of the instrument, it was submitted for face validation, a blank space was provided for each item statement, in case the expert would provide additional comment or suggestion for the improvement of instrument (Masuwai et al., 2016).

\section{Expert Review of the Instrument \\ Face Validity}

The face validity for school mathematics content test was established by the responses of the judges who examined the appropriateness and adequacy of the items on whether or not they considered the items are measuring pre-service mathematics teachers' level of knowledge of school mathematics subject matter and are relevant with objectives of the study (Yassir et al., 2016). These five judges examined the suitability of the school mathematics content test and appropriateness of item setting, clarity of instructions, appropriateness of language used and method of questioning. Based on the judges' comments and suggestions on the instrument, items that did not meet the requirement were revised, rewritten or discarded. 49 out of 50 items that was send to judges for validation were agreed as appropriate and in agreement with objective of the study and covered contents areas to be explored by the judges. However, based on the panel of experts' suggestion, item 9 was suggested to be re-casted and it was replaced by new item. Typographical error was 
INTERNATIONAL JOURNAL OF ACADEMIC RESEARCH IN BUSINESS AND SOCIAL SCIENCES

Vol. 10, No. 7, July, 2020, E-ISSN: 2222-6990 @ 2020 HRMARS

corrected based on the suggestion from panel of experts in items 43 and 49 . Table 3.6 summarized the distribution of items for the original and revised items.

Table 1

Distribution of Items in School Mathematics Contents Test

SECTION A: MULTIPLES CHOICE QUESTIONS

\begin{tabular}{|c|c|c|}
\hline $\mathrm{S} / \mathrm{N}$ & Original Items & Revised Items \\
\hline \multirow[t]{4}{*}{9} & $\begin{array}{l}\text { Which of the following logic is not } \\
\text { true? }\end{array}$ & $\begin{array}{l}\text { A sequence in which the term differ by } \\
\text { common ratio } r \text { is called }\end{array}$ \\
\hline & A. $2^{3} / 2^{5}=2^{25} \quad$ B. $2^{3} / 2^{5}=2^{5-3}$ & A. Series $\quad$ B. Sequence \\
\hline & D. $1 / x^{-3}=x^{3} / 1$ & C. Geometric Progressions \\
\hline & & D. Arithmetic Progressions \\
\hline 43 & $\begin{array}{l}\text { In equality written mathematically, In } \\
\text { equality represented graphically, In } \\
\text { equality in words. }\end{array}$ & $\begin{array}{l}\text { Inequality written mathematically, inequality } \\
\text { represented graphically, inequality in words. }\end{array}$ \\
\hline 49 & $\begin{array}{l}\text { Use the sketch in } 18 \text { above to } \\
\text { determ9ine } 1-\cos ^{2} \theta\end{array}$ & $\begin{array}{l}\text { Use the sketch in } 18 \text { above to determine 1- } \\
\cos ^{2} \theta\end{array}$ \\
\hline
\end{tabular}

\section{Content Validity}

Content validity is concerned with evaluation of each item in the instrument on whether the items are adequate, relevant and represent all facets of the construct. It however, requires each items of the instrument to be evaluated on whether the items are measuring the target construct. The process requires expert to assess appropriateness of the instrument in terms of clarity, wording, and scoring, and ensure the items of the instrument represent the target construct (Krikorian, 2016; Yassir, Mclntyre, \& Bearn, 2016).

After face validity was established, the instrument was subjected to five experts for contents validity to measure appropriateness of the items, coverage of objectives and whether or not they considered the items are measuring the target construct. The experts were asked to judge and rate the appropriateness of the items using 4-point scale: 1= Very Inappropriate, 2= inappropriate, 3= Appropriate, 4= Very Appropriate (Polit \& Beck, 2004). The expert judgment was quantified by Content Validity Index (CVI). Content Validity Index (CVI) is "the degree to which an instrument has an appropriate sample of items for the construct being measured" (Polit \& Beck, 2004).

Content Validity Index (CVI) was however, explained by Waltz et al. (2005) as:"whether or not the items sampled for inclusion on the tool adequacy represent the domain of content addressed by the instrument" (p. 96). Under this study, 1.00 was considered as excellent value for I-CVI, with three experts as judges, and .90 or higher value of SCVI/Ave (Lynn, 1986; Polit \& Beck, 2004). Based on the expert judgment, all items that were sent for validation have meet I-CVI criteria of excellent items in the instrument. Consequently, 50 items with excellent I-CVI were retained in the instrument. The average item-level CVIs (S-CVI/Ave) was 1 . The experts agreed that 50 items were appropriate and relevant $(I-C V I=1)$ and $I-C V I s$ averaging value of 1 was obtained. The universal agreement is around 50 that is, 50 items were all agreed by raters. This has shown the efficiency of the scale development process.

However, Polit and Beck (2004) have suggested that in case if I-CVIs are acceptable and S-CVI/Ave are acceptable, that we need not to base our decision on S-CVI/UA. But under this study S-CVI/UA 
(Universal Agreement) for the judgment was 1, the judge agreed universally that the items had excellent content validity. The result of the scale development has revealed that the instrument had a valid and reliable assessment tools for measuring pre-service mathematics teachers level of knowledge of secondary school mathematics subject matter.

\section{Discussion of the Finding}

The main objective of this study is to evaluate the validation process of School Mathematics Content Test. The finding of this study provides evidence that the validation process of the instrument were appropriate and adequately established in line with purpose of the study. The face and content validity of the instruments was established by developing table of specification and submits the instrument to panel of experts who are concern and have business with teaching and learning. The judge reviewed the suitability of the instrument, coverage of contents areas, appropriate of items setting, clarity of instruction, suitability of questioning technique and appropriateness of the language used. Based on the comments and suggestion from panel of experts, the instrument was revised and modified.

The panel of experts reviewed and comments was quantified to establish the quality of the items in the instruments in measuring final year pre-service mathematics teachers' level of knowledge of school mathematics subject matter. The instrument was judge as good and appropriate in measuring school mathematics subject matter knowledge with excellent content validity.

\section{Conclusion}

The main objective of this study is to evaluate the face and content validity of School Mathematics Subject Matter. One of the more significant finding to emerge from this study is that a table of specification was developed to decide on the number of items to be included from each topics. The validation process of the instruments was established by subjecting the instruments to different experts from mathematics education and psychometric and educational evaluation, to review the suitability of the instrument, clarity of purpose and coverage of contents areas to be explored. The judgment of the panel of experts revealed that the instrument has adequate face and contents validity, and it's adequate and suitable for measuring level of knowledge of secondary school mathematics subject matter.

The result of this study indicates that the experts had agreed that $100 \%$ of the items were appropriate with overall content validity index of the instrument S-CVI value of 1 . This research will serve as a base for future studies on how teacher education trainings are provided and groom preservice mathematics with adequate and relevant school mathematics subject matter knowledge which will enable them to discharge their duty effectively. However, future studies might be use to enhance the reliability and validity of the instrument as effective instrument for measuring secondary school mathematics subject matter

\section{Implications of the Study}

The implication of this study is that, the validation process provided adequate and reliable measurement of assessing level of knowledge of secondary school mathematics subject matter. It however, makes a noteworthy contribution to the body of knowledge, that the instrument can be used as a reliable and predictable tool for final year pre-service mathematics teacher's employment 
INTERNATIONAL JOURNAL OF ACADEMIC RESEARCH IN BUSINESS AND SOCIAL SCIENCES

Vol. 10, No. 7, July, 2020, E-ISSN: 2222-6990 @ 2020 HRMARS

when graduated. Since the assessment has provided evidences of valid and reliable validation process.

\section{References}

Anaduaka, U. S., \& Okafor, C. F. (2013). Poor performance of Nigerian students in mathematics in senior secondary certificate examination (SSCE): What is not working? Journal of Research in National Development, 11(2), 1-5.

Anakwue, F. O. (1997). A study of training programmes for school mathematics teachers in Nigeria (Unpublished doctoral dissertation). Institute of Education, University of London.

Chiwaridzo, M., Chikasha, T. N., Naidoo, N., Dambi, J. M., Tadyanemhandu, C., Munambah, Goldin, I. M., Pinkus, R. L., \& Ashley, K. (2015). Validity and reliability of an instrument for assessing case analyses in bioengineering ethics education. Science and Engineering Ethics, 21(3), 789-807. doi: 10.1007/s11948-015-9644-2.

De-Ville, P. (2010). Mentioning reflective practice in pre-service teachers. [10] EADR \& ETLC Conference Proceeding: The voice of Australian Science Teachers Reconstructing the mentoring provided by preservice lecturers, especially in the development of professional reflective practice.

Ibrahim, M. A., Wun, T. Y., \& Nordin, A. R. (2020). Implementation of Secondary School Mathematics Curriculum in Nigeria: An Evaluation Model. International Journal of Psychosocial Rehabilitation, 24(7), pp. 2380-2388.

Ibrahim, M. A., Wun, T. Y., \& Nordin, A. R. (2020). Mathematics Teacher Education training for Quality School Teachers; An Assessment of Mathematics Teaching Needs of Pre-Service Teachers'. International Journal of Psychosocial Rehabilitation, 24(4), pp. 38-47.

Ibrahim, M. A., Wun, T. Y., \& Nordin, A. R. (2018). Mathematics Teacher Education in Nigeria : 21st century skills for effective classroom instruction. Paper Presented at International Conference on Poverty \& Sustainable Society, 29-30 October, 2018, Grand Riverview Hotel, Kota Bharu, Kelantan., 148

Ibrahim, M. A., Wun, T. Y., \& Nordin, A. R. (2018). Mathematics Teacher Education in Nigeria: An Evaluation Model. A Paper Presented at International Postgraduate Conference on Research in Education, 16-18 August, Universiti Sains Malaysia, Penang.

Kaplan, R. M., Saccuzzo, K. P. (2005) Psychological testing: Principles, applications and issues (6th ed). California, Belmont, Thomson Wadsworth.

Krikorian, M. (2016). The development of the scale of contemplative practice in higher education (Doctoral dissertation). Retrieved from ProQuest Dissertations and Theses database. (UMI No: 10113306).

Kuiper, J., Thomas, H., \& Olorisade, G. O. (n.d.). Adebayo. T. A, Maiyanga, A. \& A. Mohammed.(2008). Transforming Teacher Education in Nigeria.

Lynn, M. R. (1986). Determination and quantification of content validity. Nursing research, 35, 382385

Masuwai, A. M., \& Saad, N. S. (2017). Evaluating the face and content validity of a Teaching and Learning Guiding Principles Instrument (TLGPI): A perspective study of Malaysian teacher educators. Geografia-Malaysian Journal of Society and Space, 12(3).

Masuwai, A., Tajudin, N. M., \& Saad, N. S. (2016). Evaluating the face and content validity of a teaching and learning guiding principles instrument (TLGPI): A perspective study of malaysian 
INTERNATIONAL JOURNAL OF ACADEMIC RESEARCH IN BUSINESS AND SOCIAL SCIENCES

Vol. 10, No. 7, July, 2020, E-ISSN: 2222-6990 @ 2020 HRMARS

teacher educators. Malaysian Journal of Society and Space, 12(3), $11-21$. Retrieved from http://journalarticle.ukm.my/9891/1/2x.geografia-si-mac16-

azwaniedam_\%281\%29_\%281\%29.pdf.

Mclntire, S. A., Miller, L. A. (2007). Foundations of psychological testing: A practical approach. California, Sage Publication.

Misko, J. (2010). Responding to Changing Skill Demands: Training Packages and Accredited Courses. Australia, National Centre for Vocational Education Research Ltd.

Chizanga, P. T. (2017). Content validity and test-retest reliability of a low back pain questionnaire in Zimbabwean adolescents. Archives of Physiotherapy, 7(3), 1-12. doi: 10.1186/s40945-0170031-y

NPE. (2004). National Policy on Education (Fourth). Retrieved from http://wbgfiles.worldbank.org/documents/hdn/ed/saber/supporting_doc/AFR/Nigeria/TCH /National Policy on Education.pdf

Odia, L. O., \& Omofonmwan, S. I. (2007). Educational system in Nigeria problems and prospects. Journal of Social Sciences, 14(1), 85-86.

Omorogbe, E., \& Ewansiha, J. C. (2013). The challenge of effective science teaching in Nigerian secondary schools. Academic Journal of Interdisciplinary Studies, 2(7), 181.

Polit, D. F., \& Beck, C. T. (2004). Nursing research: principles and method (7 ${ }^{\text {th }}$ ed.) Philadelphia: Lippincott, Williams, \& Wilkins.

Rabbitt, E. (2014). Accredited training: Enhancing the prominence of oral history in Australia. Oral History Australia Journal, (36), 43.

Siegfried, E. (1999). Student-Program Alignment and Teaching to Mastery. National Direct Instruction Conference Eugene, Oregon.

Sikorskii, A., \& Noble, P. C. (2013). Statistical considerations in the psychometric validation of outcome measures. Clinical Orthopaedics and Related Research, 471, 3489-3495. doi: 10.1007/s11999-013-3028-1

Thomas, R. G., and Eric, M. A. (2013). In Search of Useful Definition of Mastery. Educational Leadership, Vol. 71 (4), p. 18-23.

Waltz, C. F., Strickland, O. L., \& Lenz, E. R. (2005). Measurement in nursing and health research ( $3^{\text {rd }}$ ed.) New York: Springer Publishing Co.

Wilson, K. L., Lizzio, A., Ramsden, P. (1997) The development, validation and application of the Course Experience Questionnaire. Studies in Higher Education 22(1), 33-53.

Wong, C. Y., \& Karia, N. (2010). Explaining the competitive advantage of logistics service providers: A resource-based view approach. International Journal of Production Economics, 128(1), 51-67.

Wong, K. L., Ong, S. F., \& Kuek, T. Y. (2012). Constructing a survey questionnaire to collect data on service quality of business academics. European Journal of Social Sciences, 29, 209-21. Retrieved from http://eprints.utar.edu.my/860/1/6343.pdf.

Yassir, Y. A., Mclntyre, G. T., \& Bearn, D. R. (2016). Three questionnaires to assess the perception of fixed orthodontic therapy before, during and after treatment: Validity and reliability. European Journal of Orthodontics, 39(4), 402-410. doi: 10.1093/ejo/cjw076. 